the inefficient self-centred official rather than any deficiency revealed in the constitutional system.

More important, however, than Dr. Gladden's particular proposals for reform is the way in which, firmly and clearly, he points to weaknesses in the existing system-to lack of vision, to short-sighted economies, whether dictated by internal tradition or misguided external pressure and criticism. On the principles of promotion he writes with sense, shattering the notion that we are compelled to choose between seniority and merit, for example. He sees clearly the danger of bureaucracy, but above all his book indicates the great contribution to the public welfare which could be made by a Civil Service staffed and trained to meet the new demands, given the support of a public opinion, critical, alert and informed and alive to the central fact, to which the last report of the Civil Service Commissioners testifies, that public respect and adequate remuneration even more than past traditions are the essential factors if we are to recruit for the Civil Service in Britain men and women of the high ability and integrity its work demands.

R. BRightman

\section{ENGLISH PLACE-NAMES}

English Place-Name Elements

By A. H. Smith. Part 1: Introduction, Bibliography, The Elements A-IW, Maps. Pp. lvi +306 . Part 2 : The Elements Jafn-Ytri, Index and Maps. (English Place-Name Society, Vols. 25 and 26.) (Cambridge : At the University Press, 1956.) 35s. net each volume.

$\mathrm{T}$ EE English Place-Name Society was founded in 1922, and two years later there appeared a slim volume of some 70 pages written by Sir Allen Mawer and called "The Chief Elements used in English Place-Names". It was intended, as its preface said, to provide a companion to the county volumes that were yet to appear, and it has proved an invaluable guide. Since that time, the Society has published twenty-four volumes dealing with nineteen counties, and other volumes are in active preparation. In view of the vast amount of material already assem. bled, the time seemed appropriate for "a new and more extensive study", and the present two volumes are the result.

They present a very striking testimony to the achievement of the Society over the past thirty years or so. Such work as this can be accomplished only as the result of the most patient and meticulous scholarship guided by acute and critical judgment. Primarily, the elucidation of place-names makes a contribution to the study of language, but this is only a part of its interest. The evidence of placenames constitutes a major source for the history of early Britain, that is, for a period for which other sources are slender in amount and difficult to interpret; and the ramifications of this interest concern the archæologist and the historical geographer. These present volumes combine the expertize of the philologists with an appreciation of the problems that confront the student of early society and early landscape in Britain.

The entries are arranged in the form of a dictionary, and the space devoted to each varies from a single line to many pages; a number of entries are, in fact, in the nature of long articles. Those dealing with $b y$, ing, ham, tun, thorp and wic are of particular interest, and it is clear that the use and meaning of many names were far more complicated than could have been envisaged thirty years ago. Moreover, a complicating factor is that language is far from being static, and that names change their meaning with changing circumstances. 'Thus burna was the ancient word for stream, but it was often transferred to the names of settlements nearby and it fell into disuse as a living word for stream, to be replaced by broc. Similarly, the application of tun to enclosure, then to farmstead and so to village meant that tun came "to denote much the same kind of settlement as ham formerly did", and so ham disappeared as a living element in placename formation. The result is that ham names are most frequently encountered in the south-east and in East Anglia, while tun or ton names are more charac. teristic of the Midlands. It is through such difficulties as this that Prof. A. H. Smith threads his way with care. The entries are abundantly illustrated with examples; cross-references are frequent, and full account is taken of earlier views on this or that point.

The volumes are accompanied by. a number of maps which indicate, among other things, the distribution of Celtic and of Scandinavian place-names. The last is particularly welcome. Isaac Taylor's map of 1863, so often used in the past, has at last been superseded. The work is happily dedicated to Prof. Eilert Ekwall of the University of Lund in Sweden. He is a vice-president of the Society, and his many contributions to the study of English names, particularly his "Dictionary", have placed us all in his debt.

The volumes provide not only a stock-taking of the work so far accomplished but also a guide and stimulus for what is to come. 'The work of the English Place-Name Society constitutes one of the most important projects of scholarship, on a national scale, that are afoot. It not only illumines the dark places of our history but also furnishes a constant source of interest for those who travel about the countryside or look at its maps. The Society, and not least Prof. Smith himself, are to be warmly congratulated on this tour de force.

H. C. Darby

\section{QUANTITATIVE NEUROANATOMY}

The Organization of the Cerebral Cortex

By Dr. D. A. Sholl. Pp. xvit 125. (London: Methuen and Co., Ltd. ; New York: John Wiley and Sons, Inc., 1956.) 18s. net.

Studies on the Cerebral Cortex (Limbic Structures) By Santiago Ramón y Cajal. (Translated from the Spanish by Lisbeth M. Kraft.) Pp. xi +179 . (London : Lloyd-Luke (Medical Books), Ltd., 1955.) $27 s$. $6 d$. net.

HERE is, at present, good reason for claiming that less is known about the cerebral cortex than any other mammalian organ; at the same time, the demand for an organized body of structural and functional knowledge had increased rapidly during the past thirty years. The neurologist, the psychiatrist and the electroencephalographer are continually asking the neurophysiologist questions about mammalian behaviour which he cannot yet answer. Frequently, because the limitations of neurophysio. logy are not fully comprehended, hypothesis is confused with established fact, and elaborate struetures of explanation are built upon what was never more than scientific speculation. 